\title{
OSVRT NA ANALIZU POSLOVANJA NEPROFITNE ORGANIZACIJE
}

\author{
Mladena Bedeković, univ. spec. oec. \\ Veleučilište Virovitica \\ M.Gupca 78, Virovitica, Republika Hrvatska \\ e-mail:mladena.bedekovic@vuv.hr \\ Ivana Krizmanić, struč. spec. oec. \\ Grad Virovitica \\ Trg kralja Zvonimira 1, Virovitica, Republika Hrvatska \\ e-mail: ivana.krizmanic@virovitica.hr \\ Željka Kadlec, univ. spec. oec. \\ Veleučilište Virovitica \\ M.Gupca 78, Virovitica, Republika Hrvatska \\ e-mail: zeljka.kadlec@vuv.hr
}

\section{SAŽETAK}

Neprofitne organizacije poput Hrvatskog Crvenog križa usmjerene su rješavanju problema, ostvarivanju ciljeva organizacije i unaprjeđenju kvalitete života. Njihov cilj nije ostvarivanje vlastitog profita ili dobiti. Najčešći izvori financiranja su sredstva iz državnog proračuna, putem članarina $i$ donacija. Neprofitne organizacije obvezne su prezentirati svoje financijske izvještaje te u financijskim izvještajima iskazivati svoje prihode i rashode, izvore vlasništva, imovinu i obveze. Cilj ovog rada je na temelju analize financijskih izvještaja te izračuna izabranih financijskih pokazatelja dobiti pregled poslovanja neprofitne organizacije Gradskog društva Crvenog križa Virovitica. Horizontalna i vertikalna analiza financijskih izvještaja omogućit će dobivanje informacija koje su relevantne za upravljanje, a izračunavanjem financijskih pokazatelja za promatrane godine dodatno će se definirati financijski okvir poslovanja. Na kraju su doneseni zaključci vezani za poslovanje neprofitne organizacije Gradskog društva Crvenog križa Virovitica. lako nisu profitno orijentirane, neprofitne organizacije su važan pokretač promicanja javnog interesa, odnosno općeg dobra, bitan su čimbenik za društvo, iako je njihova uloga ponekad marginalizirana.

Ključne riječi: neprofitne organizacije; analiza; financijski izvještaji; financijski pokazatelji 


\section{UVOD}

Neprofitne organizacije su važne u društvu jer su usmjerene kako na pojedinca tako i na samo društvo. Neprofitne organizacije ne ostvaruju prihode radi stjecanja osobne dobiti, dobiti članova i drugih fizičkih i pravnih osoba, već su usmjerene na probleme i njihovo rješavanje i poboljšanje kvalitete života. Za ispunjavanje tih ciljeva nužni su ljudski i financijski resursi. Postoje i razlike i sličnosti između računovodstva neprofitnih i profitnih organizacija. Primjena dvojnog knjigovodstva i izrada financijskih izvještaja predstavljaju sličnosti, a razlike su prvenstveno u tome što se profit ne koristi kao glavni motiv poslovanja. Neprofitne organizacije sastavljaju i izrađuju bilancu, izvješće o prihodima i rashodima kao i bilješke. Financiranje neprofitnih organizacija najčešće obuhvaća zakonsko financiranje, financiranje iz gospodarske djelatnosti, člansko financiranje i darovanja. Kod neprofitnih organizacija postoje brojna ograničenja koja se odnose na trošenja sredstava.

Na primjeru neprofitne organizacije Gradskog društva Crvenog križa Virovitica analizirano je financijsko poslovanje pomoću vertikalne i horizontalne analize financijskih izvještaja te pojedinih financijskih pokazatelja kako bi se dobio uvid u poslovanje neprofitne organizacije.

\section{OBILJEŽJA NEPROFITNIH ORGANIZACIJA}

Neprofitne su organizacije izuzetno važne i predstavljaju bitan čimbenik za društvo te se kao i profitne organizacije moraju prilagođavati promjenama. Neprofitne su organizacije orijentirane uslužnim organizacijama (djelatnostima), a u poslovnoj politici su im ograničeni ciljevi i strategije (Rukavina, 1994), odnosno neprofitnoj organizaciji cilj nije ostvarivanje profita, već je to uglavnom pružanje i davanje usluga (Marić, 2018).

Ciljevi neprofitnih organizacija su društveni, kvalitativni, dugoročni i teško mjerljivi jer su altruistični, nematerijalni i usmjereni su ljudima. Neprofitne organizacije se osnivaju kao zaklade, udruge, ustanove, fondacije, vjerske i druge zajednice, sindikati (Pavičić, 2003), sportske organizacije i političke stranke (Botički i sur., 2017).

Prema Vašiček i Vašiček (2016) neprofitne organizacije ovisno o vlasništvu, osnivačima ili osnivačkim pravima možemo podijeliti na:

1. državne neprofitne organizacije (tijela državne vlasti, državne uprave, jedinica lokalne uprave i samouprave, pravne osobe kojima se u proračunu osiguravaju sredstva za plaće i/ili izdaci i proračunske jedinice lokalne uprave i samouprave kao što su fakulteti, škole, sveučilišta),

2. nedržavne neprofitne organizacije,

3. privatne neprofitne organizacije,

4. javne neprofitne organizacije.

Marić (2018) navodi da su u odnosu na profitne organizacije jasno vidljive razlike u društveno-ekonomskim čimbenicima, organizacijskim razinama i razinama pojedinaca. $U$ tablici 1. prikazane su ključne razlike među neprofitnih i profitnih organizacija. 
Tablica 1. Ključne razlike među profitnim i neprofitnim organizacijama

\begin{tabular}{|l|l|l|}
\hline Pokazatelj & Profitna organizacija & Neprofitna organizacija \\
\hline Vlasnik & ulagači, dioničari & $\begin{array}{l}\text { druga neprofitna organizacija, } \\
\text { privatno lice, nitko }\end{array}$ \\
\hline $\begin{array}{l}\text { Mogu li ostvariti/dijeliti } \\
\text { profit }\end{array}$ & da/da & da/da \\
\hline Osnovni izvori kapitala & $\begin{array}{l}\text { osnivačke dionice, prihodi } \\
\text { zadržana dobit i drugo }\end{array}$ & $\begin{array}{l}\text { državni fondovi, sponzorstva, donacije, } \\
\text { pokloni, članarine, prodaja usluga i roba, } \\
\text { projekti }\end{array}$ \\
\hline Plaćaju li porez & plaćaju sve poreze & ne plaćaju ili plaćaju samo neke \\
\hline Svrha organizacije & $\begin{array}{l}\text { ostvarivanje dobiti za } \\
\text { vlasnike }\end{array}$ & ostvarivanje misije i društvene koristi \\
\hline Mjere uspješnosti & $\begin{array}{l}\text { visina dobiti, povratak } \\
\text { dobiti, povratak investicija }\end{array}$ & uspješnost u ostvarivanju ciljeva \\
\hline Tko utječe na uspjeh? & potrošači & javnost, klijenti, suradnici \\
\hline
\end{tabular}

Izvor: Marić, I. (2018): Menadžment neprofitnih organizacija. Zagreb: Ekonomski fakultet - Zagreb

\section{FINANCIJSKO IZVJEŠTAVANJE NEPROFITNIH ORGANIZACIJA}

Zakonodavni okvir reguliranja računovodstvenog sustava neprofitnih organizacija temelji se na Zakonu o financijskom poslovanju i računovodstvu neprofitnih organizacija (NN 121/2014), Uredbi o računovodstvu neprofitnih organizacija (NN 10/2008), Pravilniku o sustavu financijskog upravljanja i kontrola te izradi i izvršavanju financijskih planova neprofitnih organizacija (NN 119/15), Pravilniku o neprofitnom računovodstvu i računskom planu (NN 1/2015). Prema Pravilniku o izvještavanju u neprofitnom računovodstvu i Registru neprofitnih organizacija (NN 31/2015) neprofitne organizacije vode dvojno knjigovodstvo ili jednostavno knjigovodstvo u skladu sa zakonskim propisima. Neprofitne organizacije koje poslovanje evidentiraju prema dvojnom knjigovodstvu obavezne su izrađivati financijske izvještaje koji se sastavljaju na obrascima: Bilanca (BIL-NPF), Izvještaj o prihodima i rashodima (PR-RAS-NPF), Skraćeni Izvještaj o prihodima i rashodima na Obrascu: S-PR-RAS-NPF ${ }^{1}$ odnosno ukoliko primjenjuju jednostavno knjigovodstvo neprofitna organizacija sastavlja Godišnji financijski izvještaj o primicima i izdacima (G-PR-IZ-NPF).

U skladu s Uputom Ministarstva financija² koja se odnosi na neprofitne organizacije, godišnji financijski izvještaji u dvojnom knjigovodstvu sastoje se od Bilance (BIL-NPF), Izvještaja o prihodima i rashodima na Obrascu: PR-RAS-NPF te Bilješki za poslovnu godinu. Ti izvještaji moraju pružiti informacije o poslovanju i financijskom položaju neprofitne organizacije. Tako su primjerice financijske izvještaje za 2020. godinu dužne predati neprofitne organizacije koje:

1 Pravilnikom o izmjeni Pravilnika o izvještavanju u neprofitnom računovodstvu i Registra neprofitnih organizacija izmijenjen je sadržaj obrasca PR-RAS-NPF.

2 U skladu sa Uputom za izradu i predaju financijskih izvještaja neprofitnih organizacija za razdoblje od 1. siječnja do 31. prosinca 2020. 
1. su osnovane u 2020. godini,

2. od čijeg su osnivanja prošle tri ili manje godina,

3. su osnovane ranijih godina, a vrijednost imovine i/ili ukupni godišnji prihod veći je od $230000 \mathrm{kn}$,

4. vode dvojno knjigovodstvo iako udovoljavaju uvjetima za vođenje jednostavnog knjigovodstva.

Bilanca mora pružiti informacije koje su istinite, pouzdane i točne, a sastavlja se na temelju skupina računa iz glavne knjige (Proklin, 1995). Kod neprofitnih organizacija prihodi se ostvaruju iz različitih izvora. Rashodi nastaju kao rezultat obavljanja djelatnosti neprofitne organizacije, a mogu biti rashodi za usluge, rashodi za zaposlene te ostali rashodi sadržani u Izvještaju o prihodima i rashodima (Mahaček, Mijoč, Hruška, 2012). Neprofitne organizacije dužne su sastavljati i predavati polugodišnje izvješće o prihodima i rashodima kao i godišnji financijski izvještaj u određenom roku koji je definiran Pravilnikom o izvještavanju u neprofitnom računovodstvu i Registru neprofitnih organizacija (NN 31/15 i 67/17). Izvješća se predaju FINA-i koja izvještaje zaprima te ih obrađuje za potrebe Ministarstva financija. Financiranje neprofitnih organizacija obuhvaća zakonsko financiranje, financiranje iz gospodarske djelatnosti, člansko financiranje i darovanja (Botički i sur., 2017), a Ministarstvo financija vodi Registar neprofitnih organizacija.

\section{ANALIZA POSLOVANJA NEPROFITNE ORGANIZACIJE HRVATSKI CRVENI KRIŽ VIROVITICA}

Hrvatski Crveni križ, kao neprofitna pravna osoba, djeluje na području cijele Hrvatske na način da promiče i ostvaruje humanitarne ciljeve te programe od opće koristi. Osim što se bavi rješavanjem humanitarnih, zdravstvenih i socijalnih pitanja, zadužen je za pripremu stanovništva prilikom pojave katastrofa i nesreća te u uklanjanju posljedica istog. U Republici Hrvatskoj rad Crvenog križa reguliran je Zakonom o Hrvatskom Crvenom križu (NN 71/10, 136/20) i Statutom Hrvatskog Crvenog križa (NN 56/2016). Hrvatski Crveni križ djeluje kao 131 županijsko, gradsko i općinsko društvo Crvenog križa (Hrvatski Crveni križ, 2021).

Analiza poslovanja neprofitne organizacije napravljena je na temelju Bilance i Izvještaja o prihodima i rashodima na primjeru Hrvatskog Crvenog križa Gradsko društvo Crvenog križa Virovitica (GDCK Virovitica). Napravljena je horizontalna i vertikalna analiza bilance te su izračunati odabrani financijski pokazatelji. Analiza je obuhvatila 2017., 2018., i 2019. godinu. ${ }^{3}$ Kao bazna godina pri horizontalnoj analizi uzeta je 2017. godina te su podaci za 2018. i 2019. godinu stavljani u odnos s baznom godinom. U tablici 2. prikazana je horizontalna analiza bilance za promatrano razdoblje.

3 U vrijeme pisanja rada nisu bili dostupni financijski izvještaji neprofitne organizacije za 2020. godinu. 
Tablica 2. Horizontalna analiza bilance za 2018. i 2019. godinu

\begin{tabular}{|c|c|c|c|c|c|c|c|c|}
\hline \multirow[b]{2}{*}{ OP } & \multirow[b]{2}{*}{ Opis } & \multirow{2}{*}{$\begin{array}{c}2017 . \\
\text { godina }\end{array}$} & \multirow{2}{*}{$\begin{array}{l}2018 . \\
\text { godina }\end{array}$} & \multirow{2}{*}{$\begin{array}{l}2019 . \\
\text { godina }\end{array}$} & \multicolumn{2}{|c|}{ 2018./2017. } & \multicolumn{2}{|c|}{ 2019./2017. } \\
\hline & & & & & $\begin{array}{l}\text { Iznos } \\
+/-\end{array}$ & $\begin{array}{c}\% \\
+/-\end{array}$ & $\begin{array}{l}\text { Iznos } \\
+/-\end{array}$ & $\begin{array}{c}\% \\
+/-\end{array}$ \\
\hline \multicolumn{9}{|c|}{ AKTIVA } \\
\hline & $\begin{array}{l}\text { IMOVINA } \\
(002+074)\end{array}$ & 2.667.709 & 3.165 .997 & 5.062 .087 & 498.288 & 18,68 & 2.394 .378 & 89,75 \\
\hline 0 & $\begin{array}{l}\text { 0. Nefinancijska } \\
\text { imovina }\end{array}$ & 2.184 .306 & 2.193.352 & 2.453 .643 & 9.046 & 0,41 & 269.337 & 12,33 \\
\hline 02 & $\begin{array}{l}\text { Proizvedena } \\
\text { dugotrajna } \\
\text { imovina } \\
(002+006+010 \\
+012-014)\end{array}$ & 2.184 .306 & 2.193 .352 & 2.370 .641 & 9.046 & 0,41 & 186.335 & 8,53 \\
\hline 021 & $\begin{array}{l}\text { Građevinski } \\
\text { objekti } \\
(003+004+005)\end{array}$ & 3.267 .108 & 3.194 .383 & 3.194 .383 & -72.725 & $-2,23$ & -72.725 & $-2,23$ \\
\hline 0211 & Stambeni objekti & 822.476 & 822.476 & 822.476 & 0 & 0,00 & 0 & 0,00 \\
\hline 0212 & Poslovni objekti & 2.436 .636 & 2.339 .536 & 2.339 .536 & -97.100 & $-3,99$ & -97.100 & $-3,99$ \\
\hline 0213 & $\begin{array}{l}\text { Ostali građevinski } \\
\text { objekti }\end{array}$ & 7.996 & 32.371 & 32.371 & 24.375 & 304,84 & 24.375 & 304,84 \\
\hline 022 & $\begin{array}{l}\text { Postrojenja i } \\
\text { oprema }\end{array}$ & 384.431 & 411.618 & 404.420 & 27.187 & 7,07 & 19.989 & 5,20 \\
\hline 0221 & $\begin{array}{l}\text { Uredska oprema i } \\
\text { namještaj }\end{array}$ & 113.090 & 113.090 & 104.822 & 0 & 0,00 & -8.268 & $-7,31$ \\
\hline 0223 & $\begin{array}{l}\text { Oprema za } \\
\text { održavanje i } \\
\text { zaštitu }\end{array}$ & 3.877 & 3.877 & 3.877 & 0 & 0,00 & 0 & 0,00 \\
\hline 0227 & $\begin{array}{l}\text { Uređaji, strojevi i } \\
\text { oprema za ostale } \\
\text { namjene }\end{array}$ & 267.464 & 294.651 & 295.721 & 27.187 & 10,16 & 28.257 & 10,56 \\
\hline 023 & $\begin{array}{l}\text { Prijevozna } \\
\text { sredstva }\end{array}$ & 472.009 & 287.013 & 522.768 & -184.996 & $-39,19$ & 50.759 & 10,75 \\
\hline 0231 & $\begin{array}{l}\text { Prijevozna } \\
\text { sredstva u } \\
\text { cestovnom } \\
\text { prometu }\end{array}$ & 472.009 & 287.013 & 522.768 & -184.996 & $-39,19$ & 50.759 & 10,75 \\
\hline 026 & $\begin{array}{l}\text { Nematerijalna } \\
\text { proizvedena } \\
\text { imovina }\end{array}$ & 2.806 & 2.806 & 2.806 & 0 & 0,00 & 0 & 0,00 \\
\hline 0261 & $\begin{array}{l}\text { Ulaganja u } \\
\text { računalne } \\
\text { programe }\end{array}$ & 2.806 & 2.806 & 2.806 & 0 & 0,00 & 0 & 0,00 \\
\hline
\end{tabular}




\begin{tabular}{|c|c|c|c|c|c|c|c|c|}
\hline \multirow[b]{2}{*}{$\mathrm{OP}$} & \multirow[b]{2}{*}{ Opis } & \multirow{2}{*}{$\begin{array}{l}2017 . \\
\text { godina }\end{array}$} & \multirow{2}{*}{$\begin{array}{l}2018 . \\
\text { godina }\end{array}$} & \multirow{2}{*}{$\begin{array}{l}2019 . \\
\text { godina }\end{array}$} & \multicolumn{2}{|c|}{ 2018./2017. } & \multicolumn{2}{|c|}{ 2019./2017. } \\
\hline & & & & & $\begin{array}{l}\text { Iznos } \\
+/-\end{array}$ & $\begin{array}{c}\% \\
+/-\end{array}$ & $\begin{array}{l}\text { Iznos } \\
+/-\end{array}$ & $\begin{array}{c}\% \\
+/-\end{array}$ \\
\hline 029 & $\begin{array}{l}\text { Ispravak } \\
\text { vrijednosti } \\
\text { proizvedene } \\
\text { dugotrajne } \\
\text { imovine }\end{array}$ & 1.942 .048 & 1.702 .468 & 1.753 .736 & -239.580 & $-12,34$ & -188.312 & $-9,70$ \\
\hline 1 & $\begin{array}{l}\text { 1. Financijska } \\
\text { imovina } \\
(016+019+021)\end{array}$ & 483.403 & 972.625 & 2.608 .444 & 489.222 & 101,20 & 2.125 .041 & 439,60 \\
\hline 11 & $\begin{array}{l}\text { Novac u banci i } \\
\text { blagajni }\end{array}$ & 368.285 & 829.673 & 2.426 .047 & 461.388 & 125,28 & 2.057 .762 & 558,74 \\
\hline 111 & Novac u banci & 366.252 & 825.770 & 2.422 .220 & 459.518 & 125,46 & 2.055 .968 & 561,35 \\
\hline 113 & Novac u blagajni & 2.033 & 3.903 & 3.827 & 1.870 & 91,98 & 1.794 & 88,24 \\
\hline 12 & $\begin{array}{l}\text { Depoziti, } \\
\text { jamčevni polozi } \\
\text { i potraživanja od } \\
\text { radnika te za više } \\
\text { plaćene poreze i } \\
\text { ostalo }\end{array}$ & 460 & 0 & 14.470 & -460 & $-100,00$ & 14.010 & 3045,65 \\
\hline 129 & $\begin{array}{l}\text { Ostala } \\
\text { potraživanja }\end{array}$ & 460 & 0 & 14.470 & -460 & $-100,00$ & 14.010 & 3045,65 \\
\hline 16 & $\begin{array}{l}\text { Potraživanja za } \\
\text { prihode }\end{array}$ & 114.658 & 142.952 & 167.927 & 28.294 & 24,68 & 53.269 & 46,46 \\
\hline \multicolumn{9}{|c|}{ PASIVA } \\
\hline & $\begin{array}{l}\text { OBVEZE I VLASTITI } \\
\text { IZVORI }\end{array}$ & 2.667 .709 & 3.165 .977 & 5.062 .087 & 498.268 & 18,68 & 2.394 .378 & 89,75 \\
\hline 22 & $\begin{array}{l}\text { 2. Obveze } \\
(022+037)\end{array}$ & 220.544 & 539.322 & 2.033 .566 & 318.778 & 144,54 & 1.813 .022 & 822,07 \\
\hline 23 & $\begin{array}{l}\text { Obveze za } \\
\text { rashode } \\
(024+029)\end{array}$ & 154.946 & 187.853 & 1.946 .138 & 32.907 & 21,24 & 1.791.192 & 1156,01 \\
\hline 24 & Obveze za radnike & 89.686 & 115.409 & 350.837 & 25.723 & 28,68 & 261.151 & 291,18 \\
\hline 25 & $\begin{array}{l}\text { Obveze za plaće } \\
\text { - neto }\end{array}$ & 65.260 & 73.619 & 238.139 & 8.359 & 12,81 & 172.879 & 264,91 \\
\hline 26 & $\begin{array}{l}\text { Obveze porez i } \\
\text { prirez na dohodak } \\
\text { iz plaće }\end{array}$ & 4.040 & 4.686 & 6.843 & 646 & 15,99 & 2.803 & 69,38 \\
\hline 27 & $\begin{array}{l}\text { Obveze za } \\
\text { doprinose iz plaće }\end{array}$ & 17.313 & 20.753 & 57.193 & 3.440 & 19,87 & 39.880 & 230,35 \\
\hline
\end{tabular}




\begin{tabular}{|c|c|c|c|c|c|c|c|c|}
\hline \multirow[b]{2}{*}{ OP } & \multirow[b]{2}{*}{ Opis } & \multirow{2}{*}{$\begin{array}{l}2017 . \\
\text { godina }\end{array}$} & \multirow{2}{*}{$\begin{array}{l}2018 . \\
\text { godina }\end{array}$} & \multirow{2}{*}{$\begin{array}{l}2019 . \\
\text { godina }\end{array}$} & \multicolumn{2}{|c|}{ 2018./2017. } & \multicolumn{2}{|c|}{ 2019./2017. } \\
\hline & & & & & $\begin{array}{c}\text { Iznos } \\
+/-\end{array}$ & $\begin{array}{c}\% \\
+-\end{array}$ & $\begin{array}{c}\text { Iznos } \\
+/-\end{array}$ & $\begin{array}{l}\% \\
+-\end{array}$ \\
\hline 28 & $\begin{array}{l}\text { Obveze za } \\
\text { doprinose na } \\
\text { plaću }\end{array}$ & 13.432 & 16.351 & 48.662 & 2.919 & 21,73 & 35.230 & 262,28 \\
\hline 29 & $\begin{array}{l}\text { Obveze za } \\
\text { materijalne } \\
\text { rashode }\end{array}$ & 65.260 & 72.444 & 63.681 & 7.184 & 11,01 & -1.579 & $-2,42$ \\
\hline 30 & $\begin{array}{l}\text { Naknade ostalim } \\
\text { osobama izvan } \\
\text { radnog odnosa }\end{array}$ & 0 & 4.344 & 0 & 4.344 & 0 & 0 & 0,00 \\
\hline 31 & $\begin{array}{l}\text { Obveze } \\
\text { dobavljačima u } \\
\text { zemlji }\end{array}$ & 65.260 & 68.100 & 63.681 & 2.840 & 4,35 & -1.579 & $-2,42$ \\
\hline 32 & $\begin{array}{l}\text { Obveze za kredite } \\
\text { i zajmove }\end{array}$ & 15.000 & 0 & 0 & -15.000 & $-100,00$ & -15.000 & -100 \\
\hline 33 & $\begin{array}{l}\text { Obveze za robne i } \\
\text { ostale zajmove }\end{array}$ & 15.000 & 0 & 0 & -15.000 & $-100,00$ & -15.000 & -100 \\
\hline 34 & $\begin{array}{l}\text { Odgođeno } \\
\text { plaćanje rashoda } \\
\text { i prihodi budućih } \\
\text { razdoblja }\end{array}$ & 50.598 & 351.469 & 87.428 & 300.871 & 594,63 & 36.830 & 72,79 \\
\hline 35 & $\begin{array}{l}\text { Naplaćeni prihodi } \\
\text { budućih razdoblja }\end{array}$ & 50.598 & 351.469 & 87.428 & 300.871 & 594,63 & 36.830 & 72,79 \\
\hline 36 & $\begin{array}{l}\text { Vlastiti izvori } \\
(037+038)\end{array}$ & 2.447 .165 & 2.626 .655 & 3.028 .521 & 179.490 & 7,33 & 581.356 & 23,76 \\
\hline 37 & Vlastiti izvori & 2.201 .562 & 2.162 .083 & 2.126 .216 & -39.479 & $-1,79$ & -75.346 & $-3,42$ \\
\hline 38 & Višak prihoda & 245.603 & 464.572 & 902.305 & 218.969 & 89,16 & 656.702 & 267,38 \\
\hline
\end{tabular}

Izvor: Izračun autora na temelju podataka iz bilance GDCK Virovitica, http://ck-gdck-virovitica.eu/dokumenti/

Može se zaključiti temeljem podataka u tablici 2. kako je tijekom 2018. i 2019. godine u odnosu na 2017. godinu zabilježeno povećanje nefinancijske imovine te značajnije povećanje financijske imovine (čak 439,60 \% u 2019. godini u odnosu na 2017. godinu). Obveze su se također u obje godine povećale u odnosu na 2017. godinu, odnosno u 2018. godini za 144,54\%, a u 2019. godini za 822,07\%. Smanjenje u 2018. i 2019. godini je zabilježeno u vlastitim izvorima. No, ako uzmemo u obzir i višak prihoda koji se u obje godine povećao u odnosu na 2017. godinu, tada vidimo povećanje viška prihoda u obje promatrane godine u odnosu na 2017. godinu i to u 2018. godini za 7,33\%, a u 2019. godini za 23,76\%. Kao bazna godina koristila se 2017. godina iz razloga što u toj godini nije bilo provedbi projekata pa su i povećanja financijske imovine i obveza tijekom 2018. i 2019. godine nastala zbog provođenja raznih projekata koji su utjecali na ukupno poslovanje neprofitne organizacije. 
Također je napravljena i vertikalna analiza bilance za 2017., 2018. i 2019. godinu s ciljem dobivanja uvida u strukturu financijskih izvještaja. Rezultati dobivene analize prikazani su u tablici 3 .

Tablica. 3. Vertikalna analiza bilance za 2017., 2018. i 2019. godinu

\begin{tabular}{|c|c|c|c|c|c|c|c|}
\hline OP & Opis & $\begin{array}{l}2017 . \\
\text { godina }\end{array}$ & $\%$ & $\begin{array}{l}2018 . \\
\text { godina }\end{array}$ & $\%$ & $\begin{array}{l}2019 . \\
\text { godina }\end{array}$ & $\%$ \\
\hline \multicolumn{8}{|c|}{ AKTIVA } \\
\hline & IMOVINA (002+074) & 2.667.709 & 100,00 & 3.165.997 & 100,00 & 5.062 .087 & 100,00 \\
\hline 0 & 0. Nefinancijska imovina & 2.184.306 & 81,88 & 2.193.352 & 69,28 & 2.453 .643 & 48,47 \\
\hline 2 & $\begin{array}{l}\text { Proizvedena dugotrajna } \\
\text { imovina }(002+006+010 \\
+012-014)\end{array}$ & 2.184.306 & 81,88 & 2.193.352 & 69,28 & 2.370 .641 & 46,83 \\
\hline 21 & $\begin{array}{l}\text { Građevinski objekti } \\
(003+004+005)\end{array}$ & 3.267 .108 & 122,47 & 3.194 .383 & 100,90 & 3.194 .383 & 63,10 \\
\hline 211 & Stambeni objekti & 822.476 & 30,83 & 822.476 & 25,98 & 822.476 & 16,25 \\
\hline 212 & Poslovni objekti & 2.436 .636 & 91,34 & 2.339 .536 & 73,90 & 2.339 .536 & 46,22 \\
\hline 213 & Ostali građevinski objekti & 7.996 & 0,30 & 32.371 & 1,02 & 32.371 & 0,64 \\
\hline 22 & Postrojenja i oprema & 384.431 & 14,41 & 411.618 & 13,00 & 404.420 & 7,99 \\
\hline 221 & Uredska oprema i namještaj & 113.090 & 4,24 & 113.090 & 3,57 & 104.822 & 2,07 \\
\hline 223 & $\begin{array}{l}\text { Oprema za održavanje i } \\
\text { zaštitu }\end{array}$ & 3.877 & 0,15 & 3.877 & 0,12 & 3.877 & 0,08 \\
\hline 227 & $\begin{array}{l}\text { Uređaji, strojevi i oprema za } \\
\text { ostale namjene }\end{array}$ & 267.464 & 10,03 & 294.651 & 9,31 & 295.721 & 5,84 \\
\hline 23 & Prijevozna sredstva & 472.009 & 17,69 & 287.013 & 9,07 & 522.768 & 10,33 \\
\hline 231 & $\begin{array}{l}\text { Prijevozna sredstva u } \\
\text { cestovnom prometu }\end{array}$ & 472.009 & 17,69 & 287.013 & 9,07 & 522.768 & 10,33 \\
\hline 26 & $\begin{array}{l}\text { Nematerijalna proizvedena } \\
\text { imovina }\end{array}$ & 2.806 & 0,11 & 2.806 & 0,09 & 2.806 & 0,06 \\
\hline 261 & $\begin{array}{l}\text { Ulaganja u računalne } \\
\text { programe }\end{array}$ & 2.806 & 0,11 & 2.806 & 0,09 & 2.806 & 0,06 \\
\hline 29 & $\begin{array}{l}\text { Ispravak vrijednosti } \\
\text { proizvedene dugotrajne } \\
\text { imovine }\end{array}$ & 1.942 .048 & 72,80 & 1.702 .468 & 53,77 & 1.753 .736 & 34,64 \\
\hline 1 & $\begin{array}{l}\text { 1. Financijska imovina } \\
(016+019+021)\end{array}$ & 483.403 & 18,12 & 972.625 & 30,72 & 2.608 .444 & 51,53 \\
\hline 11 & Novac u banci i blagajni & 368.285 & 13,81 & 829.673 & 26,21 & 2.426 .047 & 47,93 \\
\hline 111 & Novac u banci & 366.252 & 13,73 & 825.770 & 26,08 & 2.422 .220 & 47,85 \\
\hline 113 & Novac u blagajni & 2.033 & 0,08 & 3.903 & 0,12 & 3.827 & 0,08 \\
\hline
\end{tabular}




\begin{tabular}{|c|c|c|c|c|c|c|c|}
\hline OP & Opis & $\begin{array}{l}2017 . \\
\text { godina }\end{array}$ & $\%$ & $\begin{array}{l}2018 . \\
\text { godina }\end{array}$ & $\%$ & $\begin{array}{l}2019 . \\
\text { godina }\end{array}$ & $\%$ \\
\hline 12 & $\begin{array}{l}\text { Depoziti, jamčevni polozi i } \\
\text { potraživanja od radnika te za } \\
\text { više plaćene poreze i ostalo }\end{array}$ & 460 & 0,02 & 0 & 0,00 & 14.470 & 0,29 \\
\hline 129 & Ostala potraživanja & 460 & 0,02 & 0 & 0,00 & 14.470 & 0,29 \\
\hline 16 & Potraživanja za prihode & 114.658 & 4,30 & 142.952 & 4,52 & 167.927 & 3,32 \\
\hline \multicolumn{8}{|c|}{ PASIVA } \\
\hline & OBVEZE I VLASTITI IZVORI & 2.667.709 & 100,00 & 3.165 .977 & 100,00 & 5.062 .087 & 100,00 \\
\hline 22 & 2. Obveze $(022+037)$ & 220.544 & 8,27 & 539.322 & 17,03 & 2.033 .566 & 40,17 \\
\hline 23 & Obveze za rashode (024+029) & 154.946 & 5,81 & 187.853 & 5,93 & 1.946 .138 & 38,45 \\
\hline 24 & Obveze za radnike & 89.686 & 3,36 & 115.409 & 3,65 & 350.837 & 6,93 \\
\hline 25 & Obveze za plaće - neto & 65.260 & 2,45 & 73.619 & 2,33 & 238.139 & 4,70 \\
\hline 26 & $\begin{array}{l}\text { Obveze porez i prirez na } \\
\text { dohodak iz plaće }\end{array}$ & 4.040 & 0,15 & 4.686 & 0,15 & 6.843 & 0,14 \\
\hline 27 & Obveze za doprinose iz plaće & 17.313 & 0,65 & 20.753 & 0,66 & 57.193 & 1,13 \\
\hline 28 & Obveze za doprinose na plaću & 13.432 & 0,50 & 16.351 & 0,52 & 48.662 & 0,96 \\
\hline 29 & $\begin{array}{l}\text { Obveze za materijalne } \\
\text { rashode }\end{array}$ & 65.260 & 2,45 & 72.444 & 2,29 & 63.681 & 1,26 \\
\hline 30 & $\begin{array}{l}\text { Naknade ostalim osobama } \\
\text { izvan radnog odnosa }\end{array}$ & 0 & 0,00 & 4.344 & 0,14 & 0 & 0,00 \\
\hline 31 & Obveze dobavljačima u zemlji & 65.260 & 2,45 & 68.100 & 2,15 & 63.681 & 1,26 \\
\hline 32 & Obveze za kredite i zajmove & 15.000 & 0,56 & 0 & 0,00 & 0 & 0,00 \\
\hline 33 & $\begin{array}{l}\text { Obveze za robne i ostale } \\
\text { zajmove }\end{array}$ & 15.000 & 0,56 & 0 & 0,00 & 0 & 0,00 \\
\hline 34 & $\begin{array}{l}\text { Odgođeno plaćanje rashoda i } \\
\text { prihodi budućih razdoblja }\end{array}$ & 50.598 & 1,90 & 351.469 & 11,10 & 87.428 & 1,73 \\
\hline 35 & $\begin{array}{l}\text { Naplaćeni prihodi budućih } \\
\text { razdoblja }\end{array}$ & 50.598 & 1,90 & 351.469 & 11,10 & 87.428 & 1,73 \\
\hline 36 & Vlastiti izvori $(037+038)$ & 2.447 .165 & 91,73 & 2.626 .655 & 82,97 & 3.028 .521 & 59,83 \\
\hline 37 & Vlastiti izvori & 2.201 .562 & 82,53 & 2.162 .083 & 68,29 & 2.126 .216 & 42,00 \\
\hline 38 & Višak prihoda & 245.603 & 9,21 & 464.572 & 14,67 & 902.305 & 17,82 \\
\hline
\end{tabular}

Izvor: Izračun autora na temelju podataka iz bilance GDCK Virovitica, http://ck-gdck-virovitica.eu/dokumenti/

U tablici 3. je prikazano kako je udio nefinancijske imovine imao trend pada sa $81,88 \% \mathrm{u}$ 2017. godini na 48,47\% u 2019. godini, ali zato je udio financijske imovine u ukupnoj aktivi imao trend rasta tijekom 2018. (30,72\%) i 2019. godine (51,53 \%). Udio obveza u ukupnoj pasivi također je porastao značajnije u 2019. godini $(40,17 \%)$ u odnosu na 2017. godinu 
(8,27\%). Stavka s najvećim udjelom u pasivi su vlastiti izvori, iako je prisutna tendencija smanjivanja udjela vlastitih izvora u promatranim godinama.

Neprofitne organizacije svoj rezultat poslovanja mjere viškom ili manjkom prihoda, dok profitne mjere visinom ostvarene dobiti ili gubitkom (Hladika i Žigman, 2012). U tablici 4. prikazani su financijski pokazatelji koji se općenito koriste za ocjenu financijske situacije neprofitnih organizacija.

Tablica 4. Odabrani financijski pokazatelji neprofitnih organizacija

\begin{tabular}{|l|l|}
\hline Pokazatelj & Način izračuna \\
\hline koeficijent pouzdanosti izvora prihoda & najveći iznos prihoda (vrsta) / ukupan prihod \\
\hline $\begin{array}{l}\text { koeficijent pouzdanosti sredstava dobivenih iz } \\
\text { državnog proračuna }\end{array}$ & donacije, potpore i subvencije / ukupan prihod \\
\hline koeficijent samodostatnosti & ukupan zarađeni prihod / ukupni rashodi \\
\hline odnos rashoda za zaposlene i ukupnih rashoda & rashodi za zaposlene / ukupni rashodi \\
\hline pokazatelj uštede & razlika prihoda i rashoda / ukupni rashodi \\
\hline koeficijent zaduženosti & $\begin{array}{l}\text { prosječne ukupne obveze / prosječna ukupna } \\
\text { imovina }\end{array}$ \\
\hline odnos prihoda & vrsta prihoda / ukupan prihod \\
\hline
\end{tabular}

Izvor: Prilagođeno prema Hladika M., Žigman A. (2012): Financijski pokazatelji za ocjenu poslovanja neprofitnih organizacija, Riznica 10/2012, str. 28. i 29.

Račun prihoda i rashoda GDCK Virovitica prikazan je u tablici 5. Prihodi imaju tendenciju rasta te su za $262,12 \%$ veći u 2019. godini u odnosu na 2017. godinu, a rashodi su za $279,4 \%$ veći u 2019. godini u odnosu na 2017. godinu. Višak prihoda najveći je bio u 2018. godini.

Tablica 5. Račun prihoda i rashoda GDCK Virovitica za 2017., 2018. i 2019. godinu

\begin{tabular}{|l|l|c|c|c|}
\hline OP & Opis & 2017. & 2018. & 2019. \\
\hline \multicolumn{3}{|c|}{ PRIHODI } & \multicolumn{2}{l|}{} \\
\hline 3 & PRIHODI (02+04+05+06+09+14+16) & 2.849 .497 & 6.641 .253 & 10.318 .597 \\
\hline 31 & Prigodi od prodaje roba i pružanje usluga & 1.799 .301 & 2.069 .682 & 1.935 .257 \\
\hline 3112 & Prihod od pružanja usluga & 1.779 .301 & 2.069 .682 & 1.935 .257 \\
\hline 32 & Prihodi od članarina i članskih doprinosa & 714 & 762 & 708 \\
\hline 33 & Prihodi po posebnim propisima & 289.996 & 310.370 & 607.042 \\
\hline 34 & Prihodi od imovine & 89.552 & 90.257 & 56.558 \\
\hline 341 & Prihodi od financijske imovine & 29 & 49 & 268 \\
\hline 342 & Prihod od nefinancijske imovine & 89.523 & 90.208 & 56.290 \\
\hline 35 & Prihod od donacija & 383.819 & 3.955 .075 & 7.473 .104 \\
\hline
\end{tabular}




\begin{tabular}{|c|c|c|c|c|}
\hline OP & Opis & 2017. & 2018. & 2019. \\
\hline 351 & Prihod od donacija iz proračuna & 354.988 & 3.584 .686 & 7.244.101 \\
\hline 353 & Prihodi od trgovačkih društava i ostalih pravnih osoba & 0 & 20.000 & 60.850 \\
\hline 354 & Prihodi od građana i kućanstva & 14.275 & 19.466 & 23.962 \\
\hline 355 & Ostali prihodi od donacija & 14.556 & 330.923 & 144.191 \\
\hline 36 & Ostali prihodi & 286.115 & 215.107 & 245.928 \\
\hline 363 & Ostali nespomenuti prihodi & 175.861 & 208.295 & 244.878 \\
\hline 37 & Prihodi od povezanih neprofitnih organizacija & 0 & 0 & 0 \\
\hline & RASHODI & & & \\
\hline 4 & RASHODI $(18+24+31+32+33+34+35)$ & 2.630 .528 & 6.203 .520 & 9.980 .060 \\
\hline 41 & Rashodi za radnike $(19+20+21)$ & 1.317 .902 & 3.570 .394 & 4.312 .776 \\
\hline 411 & Plaće & 1.101 .406 & 3.003 .853 & 3.642 .072 \\
\hline 412 & Ostali rashodi za radnike & 28.000 & 51.200 & 70.900 \\
\hline 413 & Doprinosi na plaće & 188.496 & 515.341 & 599.804 \\
\hline 4131 & Doprinosi za zdravstveno osiguranje & 169.866 & 464.404 & 599.804 \\
\hline 4132 & Doprinosi za zapošljavanje & 18.630 & 50.937 & 0 \\
\hline 42 & Materijalni rashodi & 1.274 .560 & 1.500 .304 & 1.817 .534 \\
\hline 421 & Naknade troškova radnicima & 17.864 & 84.161 & 161.341 \\
\hline 423 & Naknade članovima u predstavničkim i izvršnim tijelima & 451 & 875 & 0 \\
\hline 423 & Naknade volonterima & 2.662 & 0 & 0 \\
\hline 424 & Naknade ostalim osobama izvan radnog odnosa & 109.694 & 54.212 & 74.922 \\
\hline 425 & Rashodi za usluge & 359.359 & 356.892 & 662.197 \\
\hline 426 & Rashodi za materijal i energiju & 759.440 & 142.259 & 776.876 \\
\hline 429 & Ostali nespomenuti materijali rashodi & 25.090 & 71.604 & 142.198 \\
\hline 43 & Rashodi amortizacije & 3.038 & 22.599 & 55.638 \\
\hline 44 & Financijski rashodi & 7.501 & 8.456 & 19.568 \\
\hline 45 & Donacije & 17.744 & 1.099 .987 & 3.772 .158 \\
\hline 46 & Ostali rashodi & 9.783 & 1.780 & 2.386 \\
\hline 47 & $\begin{array}{l}\text { Rashodi vezani uz financiranje povezanih neprofitnih } \\
\text { organizacija }\end{array}$ & 0 & 1.780 & 0 \\
\hline \multicolumn{2}{|c|}{ UKUPNI RASHODI } & 2.630 .528 & 6.203 .520 & 9.980 .060 \\
\hline \multicolumn{2}{|c|}{ VIŠAK PRIHODA } & 218.969 & 437.733 & 338.537 \\
\hline
\end{tabular}

Izvor: Račun prihoda i rashoda GDCK Virovitica za 2017., 2018., 2019., http://ck-gdck-virovitica.eu/dokumenti/ 
Ako se prihodi za 2019. godinu iz tablice 5. usporede s ostvarenim prihodima Hrvatskog Crvenog križa Zagreb (HCK Zagreb), tada HCK Zagreb ima 4,66 puta veće prihode (HCK Zagreb, 2021), dok su primjerice prihodi GDCK Solin (po broju stanovnika najbliži gradu Virovitici) manji za 12,2 puta (Hrvatski Crveni križ Solin, 2021). Na rashodovnoj strani rashodi HCK Zagreb su također 4,62 puta veći (HCK Zagreb, 2021), a rashodi GDCK Solin su 11,58 puta manji od rashoda GDCK Virovitica (Hrvatski Crveni križ Solin, 2021).

$\mathrm{Na}$ izabranom primjeru neprofitne organizacije GDCK Virovitica izračunati su koeficijenti pouzdanosti izvora prihoda kako bi se uvidjelo na koji izvor prihoda se neprofitna organizacija u najvećoj mjeri oslanja te koeficijenti pouzdanosti sredstava dobiveni iz državnog proračuna za promatrane godine. U tablici 6. su prikazani rezultati.

Tablica 6. Koeficijenti pouzdanosti izvora prihoda i koeficijenti pouzdanosti sredstava dobivenih iz državnog proračuna za 2017., 2018. i 2019. godinu.

\begin{tabular}{|l|c|c|}
\hline & IZRAČUN & REZULTAT \\
\hline \multicolumn{3}{|c|}{ Koeficijenti pouzdanosti izvora prihoda } \\
\hline 2017. & $1.779 .301 / 2.849 .497$ & 0,62 \\
\hline 2018. & $3.955 .075 / 6.641 .523$ & 0,60 \\
\hline 2019. & $7.473 .104 / 10.318 .597$ & 0,72 \\
\hline \multicolumn{4}{|c|}{$383.819 / 2.849 .497$} \\
\hline 2017. & $3.955 .075 / 6.641 .253$ & 0,13 \\
\hline 2018. & $7.473 .104 / 10.318 .597$ & 0,60 \\
\hline 2019. & Koeficijenti pouzdanosti sredstava dobivenih iz državnog proračuna \\
\hline
\end{tabular}

Izvor: Izračun i izrada autora na temelju podataka iz računa prihoda i rashoda

Prema izračunatim koeficijentima pouzdanosti izvora prihoda (tablica 6.) u 2017. godini najveći su bili prihodi od pružanja usluga (62\% u ukupnim prihodima). U 2018. i 2019. godini najveći su bili prihodi od donacija (2018. godine iznosili su 60\%, a u 2019. godini $72 \%$ u ukupnim prihodima). Do povećanja je došlo uslijed provođenja projekata financiranih sredstvima Europske unije. Za zaključiti je da se GDCK Virovitica u posljednje dvije godine koje su predmet analize oslanja na prihode od donacija jer je više od polovice ukupnih prihoda osigurano iz te vrste prihoda. Na takvu strukturu prihoda mogu utjecati i brojni drugi razlozi kao što su ekonomska situacija u zemlji ili broj aktivnih neprofitnih organizacija. GDCK Virovitica bi u budućnosti trebalo ostvarivati i prihode od pružanja usluga jer ovisnost o prihodima iz donacija možda dugoročno neće biti održivo. Kod izračuna koeficijenata pouzdanosti sredstava dobivenih iz državnog proračuna, vidljivo je kako se prihodi od donacija, potpora i subvencija povećavaju iz godine u godinu te se najveća razlika vidi između 2017. godine (13\%) i 2019. godine (72\%). Najveći udio u donacijama, potporama i subvencijama odnosi se na prihode od proračuna, ali i na sredstva iz Europske unije.

Kako bi se utvrdilo koji je udio rashoda pokriven ukupnim zarađenim prihodima izračunani su koeficijenti samodostatnosti, a u tablici 7. su prikazani dobiveni rezultati. 
Tablica 7. Koeficijenti samodostatnosti za 2017., 2018. i 2019. godinu Gradskog društva Crvenog križa Virovitica

\begin{tabular}{|l|c|c|}
\hline GODINA & IZRAČUN & REZULTAT \\
\hline 2017. & $2.849 .497 / 2.630 .528$ & 1,08 \\
\hline 2018. & $6.641 .253 / 6.203 .520$ & 1,07 \\
\hline 2019. & $10.318 .597 / 9.980 .060$ & 1,03 \\
\hline
\end{tabular}

Izvor: Izračun i izrada autora na temelju podataka iz računa prihoda i rashoda

Kao što je prikazano u tablici 7. koeficijent samodostatnosti u sve tri godine prelazi vrijednost jedan ( 2017. -1,08; 2018.- 1,07; 2019.-1,03) što znači da GDCK Virovitica ipak ne ovisi o prihodima od donacija i ostalih potpora. Razlog tome je prihod od pružanja usluga s kojim GDCK Virovitica poslovanje održava stabilnim.

Odnos rashoda za zaposlene i ukupnih rashoda prikazan je u tablici 8. Vidljivo je da je u 2017. i 2018. godini rashod za zaposlene 50\% ukupnih rashoda, dok je u 2019. godini nešto manji (43\%).

Tablica 8. Odnos rashoda za zaposlene i ukupnih rashoda 2017., 2018. i 2019. godinu

\begin{tabular}{|l|c|c|}
\hline GODINA & IZRAČUN & REZULTAT \\
\hline 2017. & $1.317 .902 / 2.630 .528$ & 0,50 \\
\hline 2018. & $3.570 .394 / 6.203 .520$ & 0,58 \\
\hline 2019. & $4.312 .776 / 9.980 .060$ & 0,43 \\
\hline
\end{tabular}

Izvor: Izračun i izrada autora na temelju podataka iz računa prihoda i rashoda

Koeficijenti zaduženosti za 2017., 2018. i 2019. godinu GDCK Virovitica prikazani su u tablici 9. U ovoj tablici prikazan je udio prosječnih ukupnih obveza u prosječnoj ukupnoj imovini. Vrijednost pokazatelja trebala bi biti manja od jedan što bi značilo da je organizacija likvidna. U sve tri godine rezultat je manji od jedan pa je organizacija sposobna podmiriti svoje obveze na vrijeme.

Tablica 9. Koeficijent zaduženosti za 2017., 2018. i 2019. godinu

\begin{tabular}{|l|c|c|}
\hline GODINA & IZRAČUN & REZULTAT \\
\hline 2017. & $220.544 / 2.667 .709$ & 0,08 \\
\hline 2018. & $539.322 / 3.165 .977$ & 0,17 \\
\hline 2019. & $2.033 .566 / 5.062 .087$ & 0,40 \\
\hline
\end{tabular}

Izvor: Izračun i izrada autora na temelju podataka iz bilance 
U tablici 10. prikazano je kakva je sposobnost organizacije za povećanje vlastitih izvora (ukoliko je koeficijent veći od 1, tada se povećavaju vlastiti izvori). Kod pokazatelja uštede, očekuje se da vrijednost pokazatelja bude veća od jedan, no općenito kod neprofitnih organizacija je uglavnom mala. Tako je za sve tri promatrane godine vrijednost pokazatelja uštede manja od jedan (2017. - 0,08; 2018. - 0,07; 2019. - 0,03) iz čega je vidljivo da se u GDCK Virovitica i dalje oslanjaju na tuđa sredstva.

Tablica 10. Pokazatelji uštede za 2017., 2018. i 2019. godinu

\begin{tabular}{|l|c|c|}
\hline GODINA & IZRAČUN & REZULTAT \\
\hline 2017. & $218.969 / 2.630 .528$ & 0,08 \\
\hline 2018. & $437.733 / 6.203 .520$ & 0,07 \\
\hline 2019. & $338.537 / 9.980 .060$ & 0,03 \\
\hline
\end{tabular}

Izvor: Izračun i izrada autora na temelju podataka iz računa prihoda i rashoda

Kod izračuna pokazatelja koji se naziva odnos prihoda, u odnos se stavljaju različite vrste prihoda s ukupnim prihodima. U tablici 11. su izračunati i prikazani pokazatelji koji se odnose na udio prihoda od prodaje roba i pružanja usluga, zatim udio prihoda od imovine te udio prihoda od donacija.

Tablica 11. Odnos prihoda od prodaje roba i pružanja usluga, prihoda od imovine i prihoda od donacija za 2017., 2018. i 2019. godinu

\begin{tabular}{|c|c|c|}
\hline GODINA & IZRAČUN & REZULTAT \\
\hline \multicolumn{3}{|c|}{ Udio prihoda od prodaje roba i pružanja usluga } \\
\hline 2017. & $1.799 .301 / 2.849 .497$ & 0,63 \\
\hline 2018. & 2.069 .682 / 6.641 .253 & 0,31 \\
\hline 2019. & $1.935 .257 / 10.318 .597$ & 0,19 \\
\hline \multicolumn{3}{|c|}{ Udio prihoda od imovine } \\
\hline 2017. & $89.552 / 2.849 .497$ & 0,03 \\
\hline 2018. & $90.257 / 6.641 .253$ & 0,01 \\
\hline 2019. & $56.558 / 10.318 .597$ & 0,01 \\
\hline \multicolumn{3}{|c|}{ Udio prihoda od donacija } \\
\hline 2017. & 383.819 / 2.849.497 & 0,14 \\
\hline 2018. & $3.955 .075 / 6.641 .253$ & 0,60 \\
\hline 2019. & 7.473 .104 / 10.318 .597 & 0,72 \\
\hline
\end{tabular}


U tablici 11. se može vidjeti da je udio prihoda od prodaje roba i pružanja usluga u ukupnim prihodima (63\%) te udio prihoda od imovine (3\%) bio najveći u 2017. godini. Prihodi od donacija koji podrazumijevaju prihode od donacija iz državnog proračuna, donacije iz proračuna jedinica lokane i područne (regionalne) samouprave, prihode od građana i kućanstava te ostale prihode bili su najveći u 2019. godini (72\%).

Radi usporedbe analizirani su podaci ostvarenih prihoda GDCK Solin za 2019. godinu. Razlika u odnosu na GDCK Virovitica najočitiji su po vrsti prihoda na koje se društva oslanjaju. S obzirom da GDCK Solin nema prihode od prodaje roba i usluga, a prihodi od donacija iznose manje od 1\% prihoda, društvo se velikim dijelom oslanja na prihode po posebnim propisima $(94,96 \%)$ (GDCK Solin, 2021), dok se GDCK Virovitica na tu vrstu prihoda oslanja sa svega 5,88\% (GDCK Virovitica, 2021).

Također, istraživanjem koje su proveli Bestvina Bukvić, Latković, Milinković (2016, str. 32) utvrđeno je da lokalni ogranci HCK „bilježe rast prihoda od donacija uz evidentirani višak sredstava".

\section{ZAKLJUČAK}

Neprofitne organizacije imaju važnu ulogu u životu cjelokupnog društva. Gradsko društvo Crvenog križa Virovitica, kao udruga, zadužena je za rješavanje humanitarnih pitanja, zdravstvenih i socijalnih problema kao i djelovanja prilikom katastrofa i masovnih nesreća. Na temelju financijskih podataka GDCK Virovitica napravljene su horizontalna i vertikalna analiza društva za 2017., 2018. i 2019. godinu, a izračunom pojedinih financijskih pokazatelja pružen je uvid u poslovanje samog društva. Iz provedene analize financijskih pokazatelja vidljivo je kako se GDCK Virovitica u 2017. godini više oslanjalo na prihode od pružanja usluga, dok se u ostale dvije promatrane godine oslanjalo na prihode od donacija koji zauzimaju više od 50\% ukupnih prihoda. Razlog tome je što se u 2018. i 2019. godini GDCK Virovitica više posvetilo probuđivanju svijesti o važnosti neprofitnih organizacija, dok se najveći dio donacija odnosi na prihod od donacija iz državnog proračuna, ali i sredstva Europske unije. GDCK Virovitica ipak nije ovisno o toj vrsti prihoda te je sposobno podmiriti dospjele obveze na vrijeme. 


\title{
REVIEW OF BUSINESS ANALYSIS OF A NON-PROFIT ORGANIZATION
}

\author{
Mladena Bedeković, MSc \\ Virovitica University of Applied Sciences \\ 78 Matije Gupca, Virovitica, Croatia \\ e-mail: mladena.bedekovic@vuv.hr \\ Ivana Krizmanić, MSc \\ City of Virovitica \\ 1 Trg kralja Zvonimira, Virovitica, Croatia \\ e-mail: ivana.krizmanic@virovitica.hr \\ Željka Kadlec, MSc \\ Virovitica University of Applied Sciences \\ 78 Matije Gupca, Virovitica, Croatia \\ e-mail: zeljka.kadlec@vuv.hr
}

\section{ABSTRACT}

Non-profit organizations like the Croatian Red Cross focus on achieving their own goals, solving problems and improving people's quality of life. It is not their goal to make a profit. They are financed from the state budget, through membership fees and donations. Non-profit organizations are required to disclose their assets, liabilities and sources of ownership, as well as their income and expenses. The aim of this paper is to gain insight into the operations of the City Society of the Red Cross Virovitica based on the analysis of financial statements and the calculation of selected financial indicators. Horizontal and vertical analysis of financial statements will enable obtaining information that is relevant for management, and the calculation of financial indicators for the observed years will further define the financial framework of operations. In the end, conclusions will be made regarding the business of the City Society of the Red Cross Virovitica. Non-profit organizations, despite not being profit-oriented, are a significant driver of promoting the public interest or the common good, as well as an important factor in society, even if their role is sometimes marginalized.

Keywords: non-profit organizations; analysis; financial statements; financial indicators 


\section{LITERATURA}

1. Bestvina Bukvić, I., Latković, G. i Milinković, M. (2016). Financiranje humanitarnih organizacija u kriznim uvjetima, analiza lokalnih ogranaka Crvenog križa. Razvoj Javne uprave, (6), str. 20-34.

2. Botički, J., Božina, A., Buljan, M., Cipek, K., Dremel, N., Hereg, M., ... Vuk, J. (2017). Računovodstvo neprofitnih organizacija s analitičkim računskim planom, primjerima knjiženja i propisima. Zagreb: RRiF plus d.o.o.

3. Gradsko društvo Crvenog križa Virovitica (2021). Preuzeto s http://ck-gdck-virovitica.eu/dokumenti/ (13.02.2021.)

4. Hladika, M. i Žigman, A. (2012). Financijski pokazatelji za ocjenu poslovanja neprofitnih organizacija, Riznica 10/2012.

5. Hrvatski Crveni križ Solin (2021). Financijski izvještaji neprofitnih organizacija. Preuzeto s https://www.hck-dcksdz.hr/docs/DCK-SDZ_2019_Financijski-izvjestaj.pdf (24.5.2021.)

6. Hrvatski Crveni križ Zagreb (2021). Preuzeto s https://www.hck.hr/UserDocsImages/dokumenti/ TKO\%20SMO/Pristup\%20informacijama/Revidirani\%20godi\%C5\%A1nji\%20financijski\%20izvje\%C5\%A1taji\%20za\%202019.\%20godinu.pdf (24.5.2021.)

7. Hrvatski Crveni križ. Preuzeto s https://www.hck.hr/ (13.02.2021.)

8. Mahaček, D., Mijoč, I. i Hruška, Z. (2012). Financiranje neprofitnih organizacija. Pravni vjesnik 28 (1), 173-182.

9. Marić, I. (2018). Menadžment neprofitnih organizacija. Zagreb: Ekonomski fakultet - Zagreb

10. Ministarstvo financija (2020). Uputa za izradu i predaju financijskih izvještaja neprofitnih organizacija za razdoblje od 1. siječnja do 31. prosinca 2020. Preuzeto s https://mfin.gov.hr/UserDocslmages//dokumenti/neprofitneorganizacije/fin_izvj/upute/2020//Okru\%C5\%BEnicaa\%20 2020.pdf (12.2.2021.)

11. Narodne Novine (2016). Statut Hrvatskog Crvenog križa (NN 56/2016). Zagreb: Narodne novine

12. Narodne novine (2008). Uredba o računovodstvu neprofitnih organizacija (NN 10/2008. Zagreb: Narodne novine

13. Narodne novine (2010). Zakon o Hrvatskom Crvenom križu (NN 71/2010). Zagreb: Narodne novine

14. Narodne novine (2020) Zakon o Hrvatskom Crvenom križu (NN 136/2020). Zagreb: Narodne novine

15. Narodne novine (2014). Zakon o financijskom poslovanju i računovodstvu neprofitnih organizacija (NN 121/2014). Zagreb: Narodne novine

16. Narodne novine (2015). Pravilnik o izvještavanju u neprofitnom računovodstvu i Registru neprofitnih organizacija (NN 31/2015). Zagreb: Narodne novine

17. Narodne novine (2017). Pravilnik o izvještavanju u neprofitnom računovodstvu i Registru neprofitnih organizacija (NN 67/2017). Zagreb: Narodne novine

18. Narodne novine (2015). Pravilnik o neprofitnom računovodstvu i računskom planu (NN 1/2015). Zagreb: Narodne novine

19. Narodne novine (2015). Pravilnik o sustavu financijskog upravljanja i kontrola te izradi i izvršavanju financijskih planova neprofitnih organizacija (NN 119/15). Zagreb: Narodne novine

20. Narodne novine (2018). Pravilnik o izmjeni Pravilnika o izvještavanju u neprofitnom računovodstvu i Registra neprofitnih organizacija (NN 115/2018). Zagreb: Narodne novine

21. Pavičić, J. (2003): Strategija marketinga neprofitnih organizacija. Zagreb: Masmedia d.o.o. 
22. Proklin, P. (1995). Institucionalni okvir financijskog izvještavanja u neprofitnim organizacijama. Ekonomski vjesnik, 2(8), 139-147.

23. Rukavina, K. (1994). Karakteristike neprofitnih i neprofitabilnih organizacija u odnosu na profitne i profitabilne. Ekonomski vjesnik, 1(7), 85-90.

24. Vašiček, D. i Vašiček, V. (2016). Računovodstvo proračunskih i neprofitnih organizacija. Rijeka: Ekonomski fakultet Sveučilišta u Rijeci 